betition of drought conditions such experienced in the 1930's or 188398 periods will show wastage of iwmelt to have been folly.

Precipitation data for Melfort 910-1971) shows 35 of these years th less than 16 inches and only 27 ars above this amount. Using 16 ines as a dividing point for Prince bert (1885-1949), there were 36 ars below and 27 years above. One ight advance the argument that the Ids favor dry years 4 to 3 .

In conclusion, the farmer and conrvationist must recognize their comon problem is the intelligent storage water for survival during the evitable and unpredictable dry ears.

BRAMS, G. W. 1966. Prince Albert, the first century 1866-1966. Modern Press, Saskatoon.

ONE, P. T. 1947. When the sted went throught. McMillan Co., Toronto, Ont.

HAKRAVARTI, A. K. 1969. The climate of Saskatchewan. In Atlas of Saskatchewan. University of Saskatchewan, Saskatoon, Sask.
'COGHLAN, D. O. 1972. Plans and proposals Goosehunting Creek Flosed Control Preject: Menzies Section. Wetlands Project \& Advisory Committee. Regina, Sask.

"LODGE, R. W. 1969. Agricultural use "f wetlands. In Saskatoon Wetlands Seminar. Canadian Wildlife Service Report Series 6. Ottawa, Ont.

"McKAY, G. A., J. MAYBANK, O. R. MOONEY and W. L. PELTON. 1967. The agricultural climate of Sastatchewan. Climatological Studies 10. Department of Transport, Meteorological Branch, Toronto, Ont.

'MITCHELL, J., H. C. MOSS and J. S. CLAYTON. 1950. Soil survey of Saskatche'wan Report 13. 241 p. (p. 24-27). University of Saskatchewan, Saskatoon, Sask.

${ }^{\times}$PEEL, Bruce. 1972. Steamnlexats on the Saskanchewall. Modern Press, Saskatoon, Sask.

"RENNIE, D. A. 1973. In a paper presented at Farm Week, Saskatoon, Sask.

" "SASKATCHEW AN DEPARTMENT OF AGRICULTURE. 1950. 45th Allmul Repert. March 31, 1950. First Annual Report by Director of Conservation and Development Branch. Queen's Printer, Regina, Sask. (p. 52).

' SASKATCHEWAN DEPARTMENT OF AGRICULTURE. 1972. 67th Allmual Re'port. March 31, 1972. Queen's Printer, Regina, Sask. (p. 212, Table 1A).

I'-WEDGWOOD, J. A. 1972. Drainage of werlands. Blue Jay. $30: 253$

\title{
LOOKING AT SASKATCHEWAN'S FUTURE
}

The Saskatoon Environmental Society is arranging a meeting of people from all over the province interested in sketching out possible futures for Saskatchewan, determining the environmental, social and economic implications of these alternative futures, and beginning to plan strategies and activities which will help to bring about the sorts of environmental, social and economic futures they desire.

The meeting will be held at Camp Rayner, Lake Diefenbaker, on November 3 and 4, 1973. Persons interested in attending should contact $T$. H. J. Gilmour, 1614 Ruth Street East, Saskatoon S7J OL8. 